\title{
Dewey on Language: Elements for a Non-Dualistic Approach
}

\section{Roberta Dreon}

\section{OpenEdition}

\section{Journals}

Electronic version

URL: http://journals.openedition.org/ejpap/309

DOI: $10.4000 /$ ejpap.309

ISSN: 2036-4091

\section{Publisher}

Associazione Pragma

\section{Electronic reference}

Roberta Dreon, « Dewey on Language: Elements for a Non-Dualistic Approach », European Journal of Pragmatism and American Philosophy [Online], VI-2 | 2014, Online since 24 December 2014, connection on 19 April 2019. URL : http://journals.openedition.org/ejpap/309; DOI : 10.4000/ejpap.309

This text was automatically generated on 19 April 2019

\section{(c) (i) (9)}

Author retains copyright and grants the European Journal of Pragmatism and American Philosophy right of first publication with the work simultaneously licensed under a Creative Commons AttributionNonCommercial-NoDerivatives 4.0 International License. 


\title{
Dewey on Language: Elements for a Non-Dualistic Approach
}

\author{
Roberta Dreon
}

1 John Dewey's conception of language is hardly one of the most studied aspects of his philosophical production. An important exception is represented by Max Black's article, "Dewey's Philosophy of Language", published in 1962. The British philosopher criticizes some important points in Dewey's approach: the fact that he did not have the patience to articulate the various details of linguistic cases - in particular by considering in how many different ways we can interpret the formula "taking the role of the other", central to both Dewey's own philosophy and Mead's, in order to understand language as the act of making something in common; the fact that he traced no distinctions between the meaning of a word and that of a sentence; and, above all, the fact of not having been able to get rid of the ultimate residue of the traditional conception of language, that is of the "dogma of substantive meaning", which still conceives meaning as the non-verbal counterpart of a symbol, liable to be independently designated. ${ }^{1}$ Yet, despite these criticisms, Black highlighted how radically Dewey's conception of language broke with the traditional framework, so efficaciously condensed by John Locke: language is not a mere clothing of thoughts, enabling the latter to be transferred from one mind to another (the mind being the proper place for naked thoughts); rather, it is a constitutive condition of culture and society. Furthermore, Black clearly stresses that according to Dewey language is a necessary condition for the individual mind and that it effects the transformation of the biological into the intellectual. Finally, he also emphasizes that a communicative approach to language implies a critique of the idea of private language.

What has probably proved most influential, however, for the relatively few later scholars focusing on the subject, are the opinions expressed by Rorty. While playing a central role in the promotion of Dewey's classical pragmatism, Rorty insisted on the primacy of language as opposed to that of experience, which he interpreted as a metaphysical residue in Dewey's non-dualistic and undogmatic stance. ${ }^{2}$ The result has been a debate between classical pragmatism (in particular as formulated by Dewey and James) and neopragmatism (especially in the Rortyian version), that is between the supporters of the 
alleged primacy of experience and the proponents of the centrality of language. Roughly speaking, a shift has taken place within this debate from a widespread position in favor of language, against experiential foundationalism, to a more recent trend to criticize the well-known thesis that "everything that can be understood is language". ${ }^{3}$

\section{But Are We Necessarily Obliged to Accept This Latest Form of Dualism Between Experience and Language?}

3 Recently, in a yet unpublished text, Jean-Pierre Cometti has argued that Dewey's proposals on language can be read as a linguistic turn the philosopher took before what is commonly regarded as the linguistic turn. ${ }^{4}$ Indeed, the pages the American pragmatist devoted to language now seem very innovative for the years in which they were published (from 1925 to 1938). ${ }^{5}$ These writings reflect a choice to discuss linguistic phenomena in the context of social interactions, based on the idea that meanings must be understood from their use in shared forms of action, on a critique of mentalistic and solipsistic approaches to language, and on an attempt to interpret language against the background of a clearly anti-reductionist form of cultural naturalism, far removed from dualistic oppositions between socio-cultural aspects and natural ones. Above all, the French philosopher believes that Dewey's conception of language enables us to avoid some of the risks in which the historic linguistic turn has incurred, that is the selfentanglement of language, the overemphasizing of language at the expense of the plurality of our world experiences, and the unquestioned, but sterile, supremacy of interpretation.

4 I share Cometti's view that Dewey did not think of experience and language in dualistic terms. However, there are some points where his writing might raise certain difficulties difficulties that, in my opinion, can nonetheless be solved, as I endeavor to show in this paper. ${ }^{6}$

\section{Is Communication a Water Pipe?}

5 I think that a good way to introduce the conception of language developed by the American pragmatist is offered by the notion of communication, which is consistently associated with language in his writing. This word has the disadvantage, but also the advantage, that it can be interpreted in multiple ways.

6 Certainly, Dewey's approach to language is primarily social, deeply influencing as it does the structure of his inquiry, both in Logic. The Theory of Inquiry from 1938, and in his previous book Experience and Nature, from $1925 . .^{7}$ According to the American philosopher, starting one's inquiry, as is customary, from the assumption that meanings are logical entities, existing before the linguistic sphere in which they may find expression, and from the idea that meanings exist within our minds as autonomous and already given constructs prior to social interaction leads us to typical philosophical misunderstandings regarding the phenomena under discussion. One will commit the typical philosophical fallacy of considering the results of processes of interaction as something primary rather than as end products deriving precisely from these processes; secondly, one will commit the fallacy of reifying the different phases of these processes, by treating them as independent entities. 
7 Within a theoretical framework of this kind language plays the role of a bridge or a mediator that outwardly conveys predetermined meanings, allowing them to be understood by other minds, which are in turn understood as independent entities, completely defined prior to social interaction. Here communication means the mere outside transmission of contents whose exhaustive definitions take place elsewhere, before they are made public - and in this perspective language ought to inertly convey thought, without intervening upon it, for otherwise it might distort the meaning of things.

From this point of view, the way in which language communicates is of marginal importance if compared to the definition of meanings in thought. Dewey clearly states in this regard that:

\begin{abstract}
Language thus "expresses" thought [and "expresses" is put within quotation marks because Dewey believes that linguistic expression plays a much more relevant role] as a pipe conducts water, and with even less transforming function than is exhibited when a wine-press "expresses" the juice of grapes. The office of signs in creating reflection, foresight and recollection is passed by. In consequence, the occurrence of ideas becomes a mysterious parallel addition to physical occurrences, with no community and no bridge from one to the other. ${ }^{8}$
\end{abstract}

\title{
Social Naturalism and Making Something in Common
}

For Dewey, who had embraced Darwin's9 philosophical teaching, the departure point is that no species of organism can be thought of as independent from its interactions with the surrounding environment. In the case of human beings it is almost a truism to say that man's environment is naturally social: this aspect applies to many forms of selfmoving animal life. Well ahead of many important ethological studies, The Public and its Problems, from 1927, tells us that there is nothing distinctive in this, and that we should rather ask what makes human forms of association peculiar as compared to those of other animals. ${ }^{10}$ Dewey's answer in Experience and Nature, published two years earlier, is that our environment is social in a participative way: whereas hens, when hearing the sound of corn, display self-centered forms of behavior - for each hen is driven to satisfy its own hunger and association between them is simply the result of the same need - in the case of human behavior the pursuit of a goal is, willy-nilly, cooperative: I cannot but take into account what my interlocutor does and cannot avoid "taking the role of the other". The action here is structurally shared or participatory, in the sense that in order to be accomplished it needs many individuals' contributions. This is why communication is so important for the human species, because according to Dewey it literally means the "making of something common". ${ }^{11}$ This is an important aspect, which, inter alia, deeply distinguishes Dewey's and Mead's pragmatism from the traditional phenomenological setting of the philosophical problem of understanding others. In the typically human dimension of shared social action, which is possible in virtue of language, I do not have to empathetically project onto others some alleged experiences which would otherwise be only mine; on the contrary, it is the communicative, conversational structure of language that forces me to move away from myself, from my present utterance and my present action: for I am trying to imagine what my interlocutor is going to do, having to cope with his answer (whether by accepting or rejecting it), and having to consider what consequences will derive from his behavior and my reactions to it, in view of what we are 
talking about and doing together. My role and his prove mutually determining during our linguistic interchange and our common activity in view of a given end. ${ }^{12}$

Therefore, when Dewey argues that "language is the tool of tools", ${ }^{13}$ he is emphasizing the fact that it means acting with an aim in view. But Max Black rightly points out that this formulation requires some clarification: for even a Lockean conception of language would allow us to present it as the greatest of all human instruments, as words would be seen to transmit essentially private thoughts from the speaker's mind to those of the interlocutors. In this perspective language functions as a bridge between substantially solipsistic minds and exercises its role at its best to the extent that it manages to remain inert with respect to the transmitted contents, not altering them, but returning them intact to the mind of the speaking partner, as if they were born in it. ${ }^{14}$ It is clear that Dewey means something very different from this: shared activity takes place in communicative and linguistic interchanges in particular, where social interactions "of companionship, mutual assistance, direction and concerted action in fighting, festivity and work"15 take place. From this point of view, language appears to be an active means for the coordination of common behavior, or, in other words, something constitutive of the social dimension of human behavior. ${ }^{16}$

11 As is well known, Dewey argues that the experience we have of our environment is primarily qualitative - precisely because we are structurally exposed to our environment, we feel it, rejoice or suffer for what it does to us and for what it means directly for us: danger, comfort, benefit or harm, prosperity or impoverishment. ${ }^{17}$ Quoting Franz Boas' thesis that "the two outer traits in which the distinction between the minds of animals and man finds expression are the existence of organized articulated speech in man and the use of utensils of varied application", ${ }^{18}$ the pragmatist philosopher argues that one of our most distinctive traits is our ability to reflect, or to defer the enjoyment or suffering of those things which are immediately within our reach, by considering them as a means in view of further purposes.

In this light, the instrumental function of communication and particularly of verbal language seems rather amazing. Logic: The Theory of Inquiry reminds us that artificial signs and their meanings are much more powerful than natural signs (or symbols) and those significances they are capable of signaling. While smoke already implies a certain form of representation, because it requires an inference - if I see some smoke, then somewhere there must be a fire burning - the word "smoke" may refer to smoke regardless of its existence, even in only virtual contexts, because of its multiple relations with other signs, which lend words their adaptability to the most diverse communicative situations. From this point of view, communication as the act of making something in common develops as an ordered discourse, which in each case will refer a specific context of action.

\section{Meanings and Practices: How Language and Experience Support Each Other}

But what kind of relativism is this? In order to clarify this point, it will be useful to recall a revealing example Dewey provides in his Logic.

Long before Quine's famous anecdote on the "gavagai/rabbit", presented in his essay on ontological relativity, Dewey drew a similar anthropological example from the book The Meaning of Meaning, by Ogden and Richards. A visitor is dealing with a wild tribe and asks 
a group of five or six young natives the question "What is it?", tapping his finger on a table. The answers he gets are very different: dodela, etada, bokali, elamba, meeza. One of the boys thought the visitor was asking the word for tapping with one's finger, another thought that the stranger wished to know the material out of which the table was built, another still was referring to the hardness of the wood, and only one boy referred to the table. ${ }^{19}$

Even in this case, it is worth noting the differences between Dewey's position and other kinds of approaches. Dewey was not thinking about the social use of language as in Ogden and Richards's framework in order to find a solution to the problem of connecting the alleged three vertices of a triangular pattern - the word or symbol, the object or reference, and the meaning or thought - which are understood as three autonomous entities, already completely defined before they enter into a reciprocal relationship. In an analogous way, as noted by Midtgarden, ${ }^{20}$ Dewey could not be satisfied by Morris' proposal to integrate syntax and semantics, as developed by Carnap, with a pragmatics, because the problem remained of the presupposition of signs, viewed in isolation from what they mean and from the "behavioural event in which alone they are sign". ${ }^{21}$

Besides, while Quine theorized the indeterminate status of radical translation many years later, ${ }^{22}$ Dewey in his work quotes an analogous example not in order to deny the assumed perceptual anchoring of language, but in order to argue that a translation remains indeterminate if it cannot be referred to common practices or shared linguistic customs, geared towards certain purposes. Words are defined in the context of certain social actions or, to use a different language, within certain ways of living: a certain communicative context is required - both linguistic and practical - for words to mean what they mean. From this point of view, we might say that meaning consists in verbs, that is actions, more than in nouns referring to particular entities, regarded as being preexistent to human linguistic and social activities. Indeed, "Meanings are rules for using and interpreting things; interpretation being always an imputation of potentiality for some consequences". ${ }^{23}$ If meanings are objective and non-private, it is because they are first of all "modes of natural interaction". ${ }^{24}$ Their presumed essence is not a mysterious logical or mental entity, but "the rule, comprehensive and persisting, the standardized habit, of social interaction". ${ }^{25}$

Hence, if meanings are related to contexts of action, this kind of relativity does not at all make them arbitrary; on the contrary, it enables understanding.

Now, precisely the fact that language is relative to contexts of social action and language usage geared towards the attainment of certain shared goals is what allows Dewey to emphasize that language cannot be regarded as self-referential or self-centered, because it undoubtedly requires social action contexts in order to be meaningful and not be confined to sterile indeterminateness.

On the other hand, it must be noted that this relation between language and social action contexts, between words and practices, or between meanings and forms of life, is not interpreted in foundational terms. We could say that the distinguishing feature of human sociality - which in Dewey's opinion consists in its shared structure - cannot exist apart from communication: language contributes to configuring our human way of life, but conversely it is precisely this way of life that makes language meaningful, according to a virtuous circle that is certainly non-foundational. 
20 To ask whether shared human experience serves as the foundation of language or, on the contrary, whether it is language that represents the precondition for a distinctively human experience - a participatory one, not a deaf, almost autistic form of experience is a question that does not lead anywhere, like the old, though not as noble, question of what came first, whether the chicken or the egg.

21 What is distinctive in man is that human experience and language support one another and that we can envisage experiences in which communication plays no part only as conditions quite foreign to humanity.

\section{Language and the Role of Consciousness}

Dewey's suggestion has even more radical implications, his thesis being that "communication is a condition of consciousness". ${ }^{26}$ Indeed, if we were to think of our participative forms of interaction and our sharing of experience as the result of the relations between many autonomous individual consciousnesses, we would be forgetting our existential biological matrix:

Whatever else organic life is or is not, it is a process of activity that involves an environment. It is a transaction extending beyond the spatial limits of the organism. An organism does not live in an environment; it lives by means of an environment. ${ }^{27}$

Living implies an exchange of energy involving both intra-organic and extra-organic factors, including both aspects internal to our bodies and aspects of the environment we belong to, and through which we try to restore our energies. But the point is that in the case of humans the biological matrix is also a cultural matrix, because our environment is already socially structured well before our birth, so that each individual will depend for his whole life on a socially pre-configured environment, which will continue to exist even after the individual's death. Furthermore, whereas environmental interactions are common to any form of life, human interactions are characterized by a degree of qualitative, emotive and logical complexity, by behavioral plasticity and elasticity ${ }^{28}$ in responding to one's environment, and, last but not least, by the capacity to perceive these same interactions and their consequences - that is, by our possibility of becoming conscious of them in different ways and contexts. Dewey strictly avoids dealing with the mind and consciousness in substantive terms, in order to think of them as peculiar and emerging modalities of human interaction. However, I cannot dwell on this point, because it would lead us too far.

Here I am rather interested in noting how the primacy of a socially and culturally structured environment affects our conception of language as communication - shared doing - and its relationships with thought. In this perspective, the idea that thought arises in a separate consciousness, that it is made up of mental contents, and that it must then be outwardly transmitted in order to establish social relations, is quite misleading. If we adopt the above-quoted existential, biological and cultural matrices, inner soliloquy appears to be a possibility deriving from primarily social forms of communication. Therefore, anticipating Wittgenstein's criticism of the idea of private language, and the fluid relations between language and thought which characterize the so-called linguistic turn, Dewey argues that "soliloquy is the product and reflex of converse with the others; social communication not an effect of soliloquy". ${ }^{29}$ Individual selves emerge from the part they play in shared social action, in taking part in communication understood as the act 
of making something in common. They are defined by the linguistic and practical behavior by means of which they respond to the situations they are continuously faced with. While Max Black was right in asking for a more detailed analysis of what it means from time to time to "take the part of the other", it is clear that the pragmatist philosopher had a bigger target in view: he wished to do away with the assumption that consciousness pre-exists the cooperative dimension of conversation, in favor of the thesis - carrying important ethical consequences - that everyone's part emerges during linguistic and practical intercourse, starting from the answers that each person is able to give to the others.

\section{What About Immediate Experience? More Fuzzy Limits...}

As previously noted, a certain degree of dualism seems to emerge here and there in Dewey's writing - both in Experience and Nature and in Art as Experience - in the form of an opposition between qualitative immediate experience and language conceived as ordered discourse. This is most evident in Logic. The Theory of Inquiry.

Some sentences, such as the following paragraph, give quite a clear impression that the two terms are antithetical:

But in every event there is something obdurate, self-sufficient, wholly immediate, neither a relation nor an element in a relational whole, but terminal and exclusive. Here, as in many other matters, materialists and idealists agree in an underlying metaphysics which ignores in behalf of relations and relational systems, those irreducible, infinitely plural, undefinable and indescribable qualities which a thing must have in order to be and to be capable of becoming the subject of relations and a theme of discourse. Immediacy of existence is ineffable. But there is nothing mystical about such ineffability; it expresses the fact that of direct existence it is futile to say anything to another. Discourse can but intimate connections which if followed out may lead one to have an existence. Things in their immediacy are unknown and unknowable, not because they are remote or behind some impenetrable veil of sensation or ideas, but because knowledge has no concern with them. For knowledge is a memorandum of conditions of their appearance, concerned that is with sequences, coexistences, relations. Immediate things may be pointed to by words, but not described or defined. Description when it occurs is but part of a circuitous method of pointing or denoting; index to a starting point and road which if taken may lead to a direct, ineffable presence. To the empirical thinker, immediate enjoyment and suffering are the conclusive exhibition and evidence that nature has its finalities as well as its relationships. ${ }^{30}$

It is possible to interpret this passage in a deflationary way, in an almost Wittgensteinian fashion.

Because of the structural dependence of our organism upon a naturally social environment, it follows that first of all this environment is perceived as looming over our lives, almost as a matter of survival - from the most basic needs to prosperity. From this point of view, things are first of all "aesthetic objects", that is "immediately enjoyed or suffered things", ${ }^{11}$ in which our interactions find their consummation, and a given experience simply comes to an end, without deferring any further. This is the nondogmatic meaning of the immediacy of certain experiences, of the fact that they are not instrumental towards anything else. 
But when something does not work, we need to go reflexively back to those things which had a certain impact on us, we have to analyze the various aspects of a situation which has become problematic, because we do not know how to react or what to do; so we reflect and try to understand things, to find some orientation. But in fact, when things work and do not enter into crisis, there is no need to speak about them, to try to understand them: we simply enjoy or suffer them. As Dewey states, there is nothing mystical about this: we simply do not always feel the need to say something and to reason about what happens.

No doubt, this kind of interpretation of the above quoted passage is plausible, but I will not deny the fact that there are other implications that need to be clarified.

On the one hand, we have to understand whether immediate qualitative experience is dogmatically conceived as a first neutral element and whether it is interpreted as not being subject to participation. On the other hand, we need to understand whether language is conceived in purely instrumental terms, or whether - in contrast to what Mark Johnson argues in his beautiful book The Meaning of the Body - "the need of an aesthetic of human meaning" ${ }^{32}$ can find satisfaction also in language itself. In other words, I believe that in order to solve this apparent antithesis we have to develop less rigid conceptions of language and experience, for which ample traces can indeed be found in Dewey's writings. Otherwise there is the risk of proposing yet another pair of opposites - two monolithically defined concepts - that fail to account for the complexity of our experiencing the world and speaking about it, as well as for the mutual implications between these two aspects.

I will here briefly list some arguments in favor of a "continuist" conception of the close intertwining between qualitative experience and language. ${ }^{33}$

First of all, it must be noted that the conception of qualitative experience upheld by Dewey is a non-dogmatic one: he is not, anew, proposing the myth of the given. We are very far from any attempt to found language on any kind of metaphysical datum: no doubt, things and other persons are already given in our interactions, they impose themselves upon us with genuinely intrusive force and we are not acting to construct them. However, they are not neutral atomic data we assemble in order to build knowledge; this kind of experience, which is primary just because it is not based on a reflexive consideration in actu, reveals how certain situations or things already relate to me - and not in view of other situations, things, or individuals.

We have to distinguish what makes the appeal to a given a myth or a dogma, because it is obvious that something is always already given when we utter a certain word - e.g. the natural and social environment in which we live, pre-existing social relations, the physical and physiological limits of our body - unless we are dealing with a radical idealist, of the sort often conjured up in order to have an easy argumentative target.

The point of the problem is, on the one hand, whether Dewey's call for qualitative experience is an active and foundational - that is, whether such experience is envisaged as the strong core that lends language its epistemological and/or ontological foundation and should be regarded as being foreign or structurally unrelated to language itself; besides, on the other hand, whether Dewey's qualitative experience is rather passive, a sort of inert and simple given, already determinate prior to any meaning we might later attribute. With regard to this latter aspect, it is clear that "immediate" experience is not less charged with meanings - meanings are acquired via interactions with the 
environment. Yet immediate experience primarily deals with qualitative meanings - or vital ones, we might say - rather than instrumental or cognitive ones. For the caveman as well as for the contemporary man - who are not ethereal, disembodied consciousnesses, autonomously established before their building of a bridge with the world, but rather organisms exposed to what happens around them - the natural and social environment is always felt first of all - though to different degrees - as threatening or favorable, as comfortable or stifling; and the reasons for this are not in the mind of the subject, but in the particular interactions the subject has from time to time with his/her own environment. The myth from which Dewey was here distancing himself is the claim that all of our experience may be reduced to cognition or at least that cognition itself should be taken as the eminent mode of experiencing. ${ }^{34}$ As regards the foundationalist charge, in 1939 Dewey continued to support the idea of "the derived relationship of discourse to primary experience" ${ }^{35}$ But this sentence refers to a particular, although crucial, mode of language, supporting inquiry, in the sense that it actually allows its articulation by means of its instrumental dimension, but does not exhaust our natural language in all its complexity of uses and enjoyments. ${ }^{36}$

Besides, the contrast between having an experience and knowing is not a contrast between experience and language, but between perceiving a certain situation and having the chance to consider it analytically because it has entered into crisis and one does not know what to do. To state this point more explicitly, we might argue that experience and language regard both the contexts in which things are enjoyed, suffered or even habitually used, according to an established custom, and critical situations, in which we need to solve the crux of a given matter, which inquiry must not so much represent, as contribute to solve.

Moreover, the above difference does not concern knowledge in general; rather, it is a difference between feeling and inquiring, between feeling and reasoning understood as reflexive processes in actu and not as the results of previous inquiries, as we can read in Dewey's Rejoinder from 1939. ${ }^{37}$ From this point of view, Dewey's talk of qualitative experience as "primary" might be misleading, because in this perspective it does not come first, being based on the results of previous inquiries, conducted by ourselves or by others: qualitative experience is formed by the meanings which have enriched or impoverished our interactions with the environment, which in turn can be enjoyed or suffered, perceived for what they do to us and not deferred to something other in the construction of an ordered discourse.

Finally, in the chapter of Experience and Nature entitled "Nature, life and Body-Mind", it is clear that language plays a feedback role for human sensitivity; language does not replace feeling in humans, but it contributes to configuring a peculiarly human sensitivity, which is different from that of other self-moving organisms. Dewey speaks of the natural emergence of language from life, but also of its feedback on forms of associated life, based on radical changes, so that human interactions with the environment take on peculiar modes: in short, human experience would not be the same without language.

If even inanimate beings are not considered to be isolated entities, but rather ones connected to an environment, it is clear that we are speaking about rigid relations, while animality, even in its simplest forms, is characterized by sensitivity - that is, by a capacity to selectively perceive environmental stimuli that will be experienced by a certain part of the organism for its whole body. 
41 In this sort of history of the genesis of human sensibility from animal sensitivity, an important step is represented by the new modality acquired by the interactions of selfmoving animals: only in these animals does sensitivity become feeling, because the temporal dimension of movement enables discrimination, deferment, the postponement of the consummation of an experience, and a differentiation of its phases into preparatory and final moments. Only human feeling is capable of "making sense", that is of reaching conscious forms of discrimination - conscious of both qualitative-aesthetic meanings and instrumental ones.

Feeling becomes sense in man by means of language, because it is in a communicative context that a vague feeling of the situation takes on a specific objective reference: it does not remain submerged in an indistinct whole, but emerges with a clearer outline and a broader possibility of articulation, even in view of further ends, by postponing actual enjoyments or sufferings. By way of example, Dewey mentions the distinction that may be drawn between experiencing a certain disturbing or disgusting situation and perceiving a foul odor or red blood. In order to be specified as disgust or as uneasiness, these feelings need to be "designated as signs". In short:

The qualities of situations in which organisms and surrounding conditions interact, when discriminated, make sense. Sense is distinct from feeling, for it has a recognized reference; it is the qualitative characteristic of something, not just a submerged unidentified quality or tone.

But, Dewey continues, "sense is also different from signification"38: while the sense of something is a kind of "immanent meaning" that is immediately enjoyed or suffered, signification implies the use of a quality as a sign or index for something else, for a further, temporally deferred possibility of consummation. From this point of view, linguistic symbols provide elasticity and flexibility with regard to the contents of experience, the possibility of postponement, anticipation, memory, and abstraction, not because they constitute an independent sphere compared to that of sensitivity, but because they operate in strict connection with it. To express the thesis in a Kantian style, the typical human dimension is constituted neither by transcendental aesthetics nor by logic, but by the so-called schematism where intellectual categories find themselves already sensitively configured and sensible data are given in an already oriented way.

\section{“Communion Actualized"}

44 To these arguments it must be added that in many texts Dewey emphasizes the qualitative aspects of language, not just its instrumental ones: meanings and words are not only effective means for further ends, but are also marked by a qualitative depth that is immediately perceivable - in contexts ranging from everyday intimate or more formal conversations to literature and, I would add, political discourses.

On the other hand, as revealed by the very titles of two of Dewey's papers, "Qualitative Thought" and "Affective Thought", the philosopher also stresses the qualitative components of thought, by arguing that they play an important role in thinking, where theoretical questions must be understood as answers to the qualitative depth of immediate experience. Besides, the pragmatist philosopher supports the thesis that a certain emotion or a feeling will often work as a sort of guide for the selection processes implicit in thinking, while also checking whether the conceptual tools identified are effective means of responding to an indeterminate situation. ${ }^{39}$ 

developmental terms to referential and instrumental uses of speech, as Malinowski and Jakobson have argued - and, I would add, as some recent anthropological research seems to suggest $\mathrm{t}^{43}$ - then it would be worth further exploring from this perspective the thesis developed by the young Dewey in his review of Tracy's article "The Language of Childhood". ${ }^{44}$ By disputing some results concerning the frequency of the different parts of speech in child language, Dewey put forth the idea that we should consider these first early phases of speech as characterized by a primarily holistic, syntactically indeterminate structure, from which more analytical distinctions between verbs, nouns, and so on will later develop. proceeds in an analogous fashion: starting from an overall and qualitatively oriented understanding, we switch to a more analytical form of understanding whenever necessary - whenever, that is, a certain habitual response is inadequate, but also when the stylization of speech (both in literature and in special cases in ordinary life) draws attention to it, forcing us to appreciate the importance of single aspects, in a constant switching between qualities and functions that resists sharp boundaries.

51 I shall conclude with this typically pragmatist plea to recognize that sharp boundaries are often artificial and can become dogmatic if they are envisaged as primary elements rather than as the final outcome of abstractive processes, which are justified to the extent they are assumed in view of a certain purpose. ${ }^{45} \mathrm{I}$ have argued that an approach of this 
sort can favor a non-dualistic interpretation of the connections between language and experience: something I regard as being completely in tune with Dewey's cultural naturalism, despite certain textual ambiguities, which call for more nuanced interpretations.

\section{BIBLIOGRAPHY}

BERNSTEIN R., (1961), “Dewey’s Metaphysics of Experience”, The Journal of Philosophy, 58/1, 5-14.

BLACK M., (1962), “Dewey's Philosophy of Language”, The Journal of Philosophy, 59/19, 505-523.

COMETTI J. P., (forthcoming), Le naturalisme pragmatiste. Expérience, langage et action sociale.

DEWEY J., (1939), “Experience, Knowledge and Value: A Rejoinder”, in The Philosophy of John Dewey, ed. by Schlipp P. A., La Salle: Northern University an Southern Illinois University Press, 517-608.

DEWEY J., (EW), The Early Works of J. Dewey, 1882-1898, ed. by J. A. Boydston, Southern Illinois University Press, Carbondale and Edwardsville.

DEWEY J., (LW), The Later Works of J. Dewey, 1925-1953, ed. by J. A. Boydston, Southern Illinois University Press, Carbondale and Edwardsville.

DEWEY J., (MW), The Middle Works of J. Dewey, 1899-1924, ed. by J. A. Boydston, Southern Illinois University Press, Carbondale and Edwardsville.

DEWEY J., (2007), “The Influence of Darwin on Philosophy”, in The Influence of Darwin on Philosophy and other Essays in Contemporary Thought, ed. by Hickman L., Carbondale \& Edwardsville: Southern Illinois University Press, 5-12.

DEWEy J., and BENTLEy A., (1964), John Dewey and Arthur Bentley: A Philosophical Correspondence, 1932-1951, ed. by Ratner S., and Altman J., New Brunswick: Rutgers University Press.

DISSANAYAKE E., (2003), "The Poetics of Babytalk”, Human Nature, 14, 337-364.

DREON R., (2007), Il sentire e la parola. Linguaggio e sensibilità tra filosofie ed estetiche del Novecento, Milano-Udine: Mimesis.

DREON R., (2012), “Merleau-Ponty: una concezione non soggetto-centrica dell'empatia?”, Chiasmi International, 14, 81-92.

FALK D., (2009), Finding Our Tongues. Mothers, Infant and the Origin of Language, New York: Basic Books.

GADAMER H. G., (1990), Wahrheit und Methode. Grundzüge einer philosophischen Hermeneutik, Tübingen: J. C. B. Mohr.

HILDEBRAND D., (2003a), Beyond Realism and Anti-Realism: John Dewey and the Neopragmatists, Nashville: Vanderbilt University Press.

HILDEBRAND D., (2003b), “The Neopragmatist Turn”, Southwest Philosophy Review, 19, 1, 79-88.

ноок S., (1977), "Reflections on the Metaphysics of John Dewey: Experience an Nature", Revue Intale de Philosophie, 31, 313-328, now in LW 1:1925, vii-xxiii. 
JAKOBSON R., (1963), Essais de linguistique générale, Paris: Éditions de Minuit.

JoHnson M., (2007), The Meaning of the Body. Aesthetics of Human Understanding, Chicago-London: University of Chicago Press.

KoOPMAN C., (2007), "Language is a Form of Experience: Reconciling Classical Pragmatism and Neopragmatism", Transactions of the Charles S. Pierce Society, 43, 4, 694-727.

MALINOWSKI B., "The problem of Meaning in Primitive Language”, in The Meaning of Meaning, ed. by Ogden C.K. and Richards I.A., New York: Brace \& Co., 296-355.

MCCLELland K., (2008), “John Dewey and Richard Rorty Qualitative Starting Points", Transactions of the Charles S. Pierce Society, 4, 3, 412-445.

MEAD G., (1922), “A Behaviouristic Account of Significant Symbol”, The Journal of Philosophy, 19, 6, 157-163.

MIDTGARDEn T., (2008), “Dewey's Philosophy of Language”, Revue Interationale de Philosophie, 62, 3, 257-272.

QUINE W. V. O., (1969), Ontological Relativity and Other Essays, New York: Columbia University Press. RORTY R., (1961), “Pragmatism, Categories, and Language”, The Philosophical Review, 70, 2, 197-223.

RORTY R., (1982), Consequences of Pragmatism, Minneapolis: Univ. of Minnesota Press.

SHUSTERMAN R., (1999), “Dewey on Experience: Foundation or Reconstruction?”, in Dewey Reconfigured: Essays on Deweyan Pragmatism, ed. by Haskins C. and Seiple D. I., Albany: State University of New York Press.

\section{NOTES}

1. Black (1962: 519).

2. Reference must be made here to the chapter "Dewey's Metaphysics" in Rorty 1982, where the author highlights the tension especially resulting, in his own view, from Experience and Nature (LW: 1). According to Rorty, in this book Dewey aims to solve metaphysical problems and the unhelpful dualisms they create, but at the same time does not abandon the idea of providing a description of experience as such and of identifying the basic types of interaction, that is of achieving "die Sache selbst", producing a new metaphysics. With regard to this point, I only wish to observe that Rorty does not pose the problem of whether it is possible to abstain from any sort of ontological assumption or whether this would be an improper claim to make. It should be noted, however, that when Rorty seeks to recover the pragmatist contribution on language, he turns to Peirce, as in Rorty, 1961: omissions are significant.

3. This famous thesis can of course be found in Gadamer 1960. On this debate, see Bernstein 1961, Hildebrand 2003a and 2003b, Hook 1977, Koopman 2007, Midtgarden 2008, Shusterman 1999.

4. The text I am referring to is the first draft of a new book entitled Le naturalisme pragmatiste. Expérience, langage et action sociale. I am very grateful to Jean-Pierre Cometti for allowing me to read his pages before their publication.

5. To be more accurate, I should refer as far back as to 1922 and the article "Knowledge and Speech Reaction" (Dewey MW: 13), which bears witness to Dewey's appreciation of Mead's contribution to the subject, following the publication of "A Behaviouristic Account of the Significant Symbol" (Mead 1922). 
6. Even Colin Koopman maintains that we must overcome the alleged alternative between experience and language, but he believes that it is necessary to find a third pragmatist way in addition to those of Dewey and Rorty, and that it should be possible to do so by thinking of language as simply one mode of experience among others, "not different from other forms of experience in any deep and philosophically instructive way" (Koopman 2007: 716).

7. LW 1, and LW 12.

8. LW 1: 134

9. On this point see Dewey 2007.

10. LW 2, Chapter 1.

11. LW 12: 52 .

12. For an attempt to verify whether in Merleau-Ponty's phenomenology it is possible to find a non-self-centred conception of empathy, see Dreon 2012.

13. LW 1: 134.

14. Black (1962: 507-508).

15. LW 1: 135.

16. With regard to this point, in Midtgarden 2008 an interesting answer may be found to Max Black's objection, according to which Dewey was still in need of finding a non-verbal counterpart to language, liable to be independently designated, in social activity: language is "constitutive for modes of behavioural response distributed in a social group" and is understood as "social activity". In other words, social activity cannot be represented as being alien to language and capable of being independently designated.

17. I believe that this point can find further support in Jean-Pierre Cometti's interpretation, where he argues that Darwin's influence on Dewey must be understood not only in an antiessentialistic sense, but also in a profoundly anti-telelological one: no line of evolutionary development is foreshadowed or guaranteed by a principle remaining external to evolution; whatever occurs within it - including human development, language and the mental and conscious qualities of certain interactions - is merely contingent, or, if we prefer, gratuitous, not guaranteed a priori. This is also why our vulnerability to the environment is structurally significant and for this reason, as emphasized by Sidney Hook (now in his "Introduction" to LW 1), the American pragmatist. Dewey insists on pointing out that qualities are neither properties of the experienced objects nor of the Erlebnissen of supposed private experiencing subjects. On the contrary, they are qualities of the interactions taking place between organisms and their environment, because, for example, fear or joy certainly involve someone capable of feeling them, but find their justification in the environmental conditions determining them - so that if someone feels frightened without environmental support, we say that it is a hallucinatory phenomenon.

18. LW 1: 133.

19. LW 12: 59.

20. Mitgarden 2008, recalling the exchange between Dewey and Arthur Bentley on Charles Morris (see Dewey and Bentley 1964).

21. Dewey and Bentley (1964: 282).

22. In Quine 1969.

23. LW 1: 147.

24. LW 1: 149.

25. LW 1: 149 .

26. LW 1: 147.

27. LW 12: 32 .

28. On this aspect, see MW 14.

29. LW 1: 135.

30. LW 1: 74-75.

European Journal of Pragmatism and American Philosophy, VI-2 | 2014 
31. LW 1: 75-76.

32. Johnson (2007: ix).

33. For a detailed discussion of these aspects, see Dreon (2007: Chapter 4).

34. From this point of view, it could be argued that this is a myth at least partially present also in Rorty. See David Hildebrand's characterization of Rorty's rejection of experience in favour of language as intellectualistic in Hildebrand 2003a. Moreover, in LW 12: $72 \mathrm{ff}$. the criticism levelled against the concept of sensory data is very clear. Here Dewey shows how the appeal to something given can become dogmatic when perception is restricted to sensory perception and sensory data are envisaged as the first elementary factors of knowledge, which are not further reducible. On the contrary, sensory data are discerned and assumed in view of certain hypotheses that make them relevant in order to find a solution to an indeterminate situation. In short, we should not forget that the analytical aspects of an inquiry are functional to the inquiry itself: they are its products, not its constitutive elements.

35. Dewey (1939: 546).

36. On this aspect see Midtgarden 2008, showing how a non-circular account of the language of inquiry - we might say of instrumental, cognitive and oriented language - as something not liable to be independently designated must be indirect and involve the background of natural language, including both used and enjoyed language on one hand and inquiry-oriented language on the other.

37. Dewey 1939.

38. LW 1: 200 (and preceding quotation as well).

39. LW 2 and LW 5.

40. LW 1: 160. Dewey is quoting Malinowski (1923: 475).

41. Jakobson 1963 - a famous essay devoted to language and poetry.

42. LW 1: 160.

43. See Dissanayake 2003, and Falk 2009.

44. EW 4: 66-69.

45. A charge of anti-nominalism, in Peirce's sense of the term, could perhaps be levelled against Rorty himself, who refers to the relationships between language and experience and the alleged primacy of the former or the latter. As the philosopher argues in Rorty 1961, pragmatism is not "a sort of muddle headed first approximation to logical positivism", and according to Peirce a nominalist is someone who assumes that everything that is real is or may be reduced to things that have sharp boundaries. In contrast, among the irreducible so-called Thirds which Peirce claimed as truly existing forms of vagueness, Rorty includes intelligence, signs and meanings, intentions, rules, habits. I think that we should conveniently add to this list language and experience as well.

\section{ABSTRACTS}

This paper reconstructs the merits of John Dewey's conception of language by viewing it within the context of communication as the act of making something in common, as social and instrumental action. It shows that on the one hand this approach allows us to avoid the problems of the linguistic turn: the self-entanglement of language, the overemphasizing of language at the expense of the plurality of our world experiences, and the unquestioned, but sterile, supremacy 
of interpretation. On the other hand, the paper supports the thesis that Dewey's perspective on language does not produce a new form of foundationalism - according to which language itself is founded on experience, liable to be independently designated - by providing some arguments to interpret the relationship between language and experience in non-contrastive ways. In particular, the essay suggests a non-dualistic interpretation of the distinction between immediate qualitative experience and language, that is knowing in actu, by arguing that language cannot be reduced to the ordered discourse of inquiry since it also structurally includes qualitative and aesthetic aspects.

\section{AUTHOR}

\section{ROBERTA DREON}

Ca' Foscari University Venice robdre@unive.it 